УДК $502.5 / 8$

DOI: $10.36718 / 1819-4036-2020-5-69-72$
С. Э. Бадмаева, В. И. Космаков,

Ю. В. Бадмаева, А. А. Бакач

\title{
ФОРМИРОВАНИЕ ТЕХНОГЕННОГО ЛАНДШАФТА ПРИ ДОБЫЧЕ ПОЛЕЗНЫХ ИСКОПАЕМЫХ
}

\author{
S. E. Badmaeva, V. I. Kosmakov, \\ Yu. V. Badmaeva, A. A. Bakach
}

\section{THE FORMATION OF TECHNOGENIC LANDSCAPE WHEN MINING}

Бадмаева Софья Эрдыниевна - д-р биол. наук, доц., зав. каф. кадастра застроенных территорий и планировки населенных мест Красноярского государственного аграрного университета, г. Красноярск. E-mail: s.bad55@mail.ru

Космаков Василий Игоревич - канд. с.-х. наук, директор ООО НПП «ЭКОПРИС», г. Красноярск.

E-mail: s.bad55@mail.ru

Бадмаева Юлия Владимировна - канд. с.-х. наук, доц. каф. кадастра застроенных территорий и планировки населенных мест Красноярского государственного аграрного университета, г. Красноярск. E-mail: s.bad55@mail.ru

Бакач Анастасия Александровна - магистрант каф. кадастра застроенных территорий и планировки населенных мест Красноярского государственного аграрного университета, г.Красноярск. E-mail: s.bad55@mail.ru

Цель исследования - изучение формирования техногенного ландшафрта при добьие россылного месторождения золота в бассейне р. Колоромо Северо-Енисейского района Красноярского края. Река Колоромо является правым притоком р. Чапа. Рельефр района месторождения среднегорный, интенсивно расчлененный с абсолютньми отметками водоразделов от 350 до 982 м - 2. Гаревский Полкан и относительными превышениями водоразделов над поймами рек 150400 м. Все хребты и реки вытянуты в северозападном направлении. Долина р. Колоромо асимметрична, на правом крутом борту широко развиты осыпи, курумы, а на левом пологом широкие террасо-увалы, перекрытые делювиальными шлейфрами мощностью 2-8 м. Ширина долины колеблется от 120 до 650 м, ширина русла реки 3-10 м, характерно быстрое течение, большое количество перекатов, шивер. Глубина плесов составляет 0,5-1 м. При анализе состояния техногенной территории был использован картографичческий подход, маршрутные полевые исследования. Представлены результаты исследования формирования техногенных ландшафртов. При отработке россыпных месторождений происходят значительные на-
Badmaeva Sofya Erdynievna - Dr. Biol. Sci., Prof., Head, Chair of Inventory of Built-up Territories and Layout of Populated Areas, Krasnoyarsk State Agrarian University, Krasnoyarsk.

E-mail: s.bad55@mail.ru

Kosmakov Vasily Igorevich - Cand. Agr. Sci., Director, JSC RPE 'EKOPRIS', Krasnoyarsk.

E-mail: s.bad55@mail.ru

Badmaeva Yulia Vladimirovna - Cand. Agr. Sci., Assoc. Prof., Chair of Inventory of Built-up Territories and Layout of Populated Areas, Krasnoyarsk State Agrarian University, Krasnoyarsk.

E-mail: s.bad55@mail.ru

Bakach Anastasia Alexandrovna - Magistrate Student, Chair of Inventory of Built-up Territories and Layout of Populated Areas, Krasnoyarsk State Agrarian University, Krasnoyarsk.

E-mail: s.bad55@mail.ru

рушения естественных территорий в границах нарушаемых участков, сопровождающиеся коренньми изменениями ландшафотов по пространственной структуре, и их литогенной основы. Территории, нарушенные разработками месторождений россыпного золота, представлены карьерными выемками (выработанное пространство), траншеями, отвалами вскрышных пород, отвалами промьвки, технологическими водоемами, руслами водотоков (руслоотводами). Естественные речные долины преобразуются в техногенные грядовые озерно-речные комплексы. Согласно структурным изменениям, происходящим при добьчных работах, техногенные территории подразделяются на несколько участков: русло водотока (руслоотвод), выработанное пространство, пруды-отстойники, отвалы вскрышных пород, отвалы промывки. При отработке месторождения в бассейне р. Колоромо размещение отвалов вскрышных пород производилось на бортах карьерной выемки. При разработке россыпных месторождений золота происходит изменение ландшафрта, которое зависит от применяемой технологии разработки месторождений и приводит $к$ образованию техногенных ландшафртов. Пред- 
приятия, нарушившие естественную структуру агроландшафта, должны предусмотреть мероприятия по сельскохозяйственной или лесохозяйственной рекультивации.

Ключевые слова: техногенные ландшафрты, литогенная основа, добычные работы, месторождение, отвалы, террасы.

The purpose of the research is to study the formation of technogenic landscape during the functioning of loose gold deposit in the basin of Kolomo Northern-Yenisei district of Krasnoyarsk Region. The river of Koloromo is the right inflow of the river Chap. The relief of the region is field mid-mountain, intensively dismembered with absolute marks of watersheds from 350 to $982 m-m$. Garevsky Polkan and relatively exceeding watersheds over floodplains of the rivers about 150-400 $\mathrm{m}$. All the ridges and rivers are extended in the northwest direction. The valley of the river of Koloromo is asymmetric, on the right abrupt board taluses, kurums, and on left by bed curtains - wide uval terraces blocked by the 2-8 $\mathrm{m}$ diluvial loops are widely developed. The width of the valley fluctuates from 120 to $650 \mathrm{~m}$; the width of the bed of the river is 3-10 m, rapid current, a large number of rifts, shivers are typical. The depth of the reaches makes $0.5-1 \mathrm{~m}$. In the analysis of the condition of technogenic territory cartographical approach, route field researches are used. The results of the research of the formation of technogenic landscapes are presented. At working off of loose fields there are considerable violations of natural territories in the borders of broken sites followed by basic changes of landscapes on spatial structure and their lithogenic basis. The territories broken by the development of fields of placer gold are presented by career dredging (the developed space), trenches, dumps of overburden rocks, washing dumps, technological reservoirs, courses of water currents (watercourses change). Natural river valleys will be transformed to technogenic row lake and river complexes. According to structural changes taking place during mining works, technogenic territories are subdivided into some sites: the course of waterway (watercourses change), developed space, ponds settlers, dumps of overburden breeds, washing dumps. Working off the field in the basin of the river the placement of dumps of overburden rocks was made by Koloromo on the boards of career dredging. When developing loose gold deposits there is a change of a landscape depending on the applied technology of fields and leads development to formation of technogenic landscapes. The enterprises which have broken natural structure of an agrolandscape are to provide actions for agricultural or silvicultural recultivation.

Keywords: man-made landscapes, lithogenic base, mining works, deposit, dumps, terraces.

Введение. При проведении горноподготовительных и добычных работ происходит перемещение большого количества вскрышных пород, выемка песков и их промывка, перераспределение фрракционного состава песков, поступающих на промывку, и, как следствие, коренное изменение литогенной основы ландшафта. Литогенная основа - это горные породы и рельеф дневной поверхности, слагаемый ими. Литогенная основа является производной не только горных пород, но также гидроклиматических и биотических компонентов ландшафтта [1, 4-6]. Согласно структуре нарушений, происходящих при вскрышных и добычных работах, и характеру формирования техногенного ландшафта, техногенные территории представлены сушей и обводненными участками. Обводненные участки включают в себя: русло водотока, пруды-отстойники оборотной системы водоснабжения, пруды-накопители. Территория суши представлена отвалами вскрышных пород, отвалами промывки, ненарушенными участками, расположенными внутри контура отработки, необводненным выработанным пространством. Грунты необводненного выработанного пространства представлены скальными грунтами различной степени трещиноватости.

В сильнонарушенных ландшафттах исходная структура разрушена, а средовоспроизводящие фуннкции почти не выполняются. Изучение путей и способов восстановления такого ландшафта является актуальным, в данном случае для предприятий горнодобывающей промышленности.

Цель исследования: изучить формирование техногенного ландшафтта при добыче россыпного месторождения золота в бассейне р. Колоромо Северо-Енисейского района Красноярского края.

Задачи исследования: 1) определить физико-гидрологические условия формирования техногенной территории; 2) выявить тип формируемых техногенных ландшафтов для определения направления дальнейшей рекультивации.

Объект и методы исследования. Объектом исследования является техногенная территория россыпного месторождения золота в бассейне р. Колоромо Северо-Енисейского района Красноярского края. Река Колоромо - правый приток р. Чапа. Рельеф района месторождения среднегорный, интенсивно расчлененный с абсолютными отмет- 
ками водоразделов от 350 до 982 м - г. Гаревский Полкан и относительными превышениями водоразделов над поймами рек 150-400 м. Все хребты и реки вытянуты в северо-западном направлении. Долина р. Колоромо асимметрична, на правом крутом борту широко развиты осыпи, курумы, а на левом пологом - широкие террасо-увалы, перекрытые делювиальными шлейфами мощностью 2-8 м. Ширина долины колеблется от 120 до 650 м, ширина русла реки 3-10 м, характерно быстрое течение, большое количество перекатов, шивер. Глубина плесов составляет 0,5-1 м. При анализе состояния техногенной территории был использован картографрический подход, маршрутные полевые исследования.

Результаты исследования и их обсуждение. Долина р. Колоромо расположена на северозападе осевой части Енисейского кряжа, сложенной очень древними метаморфизованными породами тейской серии нижнего протерозоя и сухопитской серии верхнего протерозоя, прорванных интрузиями татарско-аяхтинского, токминского и индыглинского комплексов. Борта долины и ее днище сложены породами кординской свиты сухопитской серии. Более всего распространены биотит-кварц-полевошпатовые сланцы, серые и черные алевросланцы, песчаники, гравелиты, конгломераты, известняки, филлиты и кварциты.

C позднего докембрия метаморфизованные породы района подвергаются выветриванию и размыву. В меловую и палеогеновую эпохи в условиях стабильного тектонического режима на коренных породах сфрормировались мощные коры выветривания. Позднее они интенсивно эродировались в депрессионные воронки и речные долины. Последнее привело к образованию россыпей золота из небольших, маломощных кварцевых жил с содержаниями золота не выше 0,20,8 г/т, которые широко развиты в породах кординской свиты и вышеназванных корах выветривания, которые подвергались дезинтеграции.

Унаследованное развитие долины р. Колоромо продолжается с мезозоя при отчетливой тектонической предопределенности. В качестве новообразований в ее морфологии достаточно отчетливо видна ледниковая неоген-четвертичная моделировка мезо- и микроформ.

Верховья р. Колоромо являются эродированным цирком, в котором происходила аккумуляция фирна с разгрузкой его ниже современного устья руч. Неразгаданного, где по левому склону долины сохранился фррагмент ригеля. Ниже долина реки представляет собою эродированный трог, по левому склону которого развиты делювиаль- но-солифлюкционные шлейфы и установлены реликты размытой конечной морены на пойме и боковые морены у подножья левого склона.

В целом долина р. Колоромо асимметрична, с четковидными расширениями и ущельевидными сужениями. Пойма интенсивно заболочена, кочковата. Ширина ее изменяется от 150 до 650 м. Эпизодически по левому борту долины сохраняются аккумулятивные террасы высотой 5-8 м с невысокой золотоносностью. Мощность рыхлых отложений в пойме 4-6 м и возрастает до 10-34 м в немногих карстово-эрозионных западениях плотика вдоль тальвега долины чуть выше устья руч. Каменистого, правого притока р. Колоромо. Продольный уклон долины реки составляет 0,009 и перепадов не имеет [2].

На момент проведения исследования техногенные дисперсные грунты были размещены в отвалах вскрышных пород и отвалах промывки. Отвалы вскрышных пород выложены по бортам контура отработки и представляют собой сформированные террасы. Отвалы вскрышных пород, нагорные канавы имели размеры и формы, созданные в процессе горноподготовительных работ. Склоны отвалов промывки характеризовались углом естественного откоса слагающих фракций. Системы отработки месторождения определяют структуру сложения отвалов. Тип применяемого оборудования определяет распределение фракций отвалов и структуру их формирования $[1,3]$. Характеристика грунтов отвалов определяется исходя из размера преобладающей фракции и продуктивного (верхнего) слоя. Формируемые техногенные ландшафрты подразделяются на несколько типов, в зависимости от характера воздействия и типов формируемых отвалов: отвалы вскрышных пород, отвалы промывки, валунные отвалы, галечные отвалы и т. д. Проведенные нами исследования показывают, что в долине $p$. Колоромо отвалы вскрышных пород были сформированы отвалами торфов, которые представлены перемешанными четвертичными отложениями, по гранулометрическому составу грунты преимущественно представлены суглинисто-гравийными (суглинисто-щебенистыми) фрракциями.

При промывке песков произошло перераспределение фрракций и формирование новых типов техногенных ландшафтов после промывки. Отвалы промывки были представлены пятью типами техногенных ландшафтов, в зависимости от типа фрормирования:

- галечные отвалы или надрешетный продукт - валунный (глыбовый), галечниковый (щебенистый), гравийный (дресвяный); 
- эфельные отвалы или подрешетный продукт - гравийный (дресвяный) с различными типами заполнителя, а также иловый (песчаный, супесчаный, глинистый), фрормируемый в ложе прудов-отстойников.

Валунные отвалы формируются при выбрасывании надрешетного продукта через гусак прибора, характеризуются преобладанием валунной (глыбовой) фракции, размером более 20 см. Грунт был хорошо промыт и продуктивная (0-20 см) часть отвалов не содержала мелких фрракций, в нижней части отвала пустоты между крупными фрракциями были заняты мелкими галечниковыми обломками, которые являлись надрешетным продуктом и были выброшены вместе с валунной фрракцией. Галечниковые фракции были перемещены в нижнюю часть отвала под воздействием гравитации и воды.

Выводы. Таким образом, проведенные исследования позволили сделать заключение о том, что метаморфизированные породы долины р. Колоромо, подвергаясь выветриванию и размыву, привели к образованию россыпей золота из маломощных кварцевых жил. В настоящее время при разработке россыпных месторождений золота происходит изменение ландшафрта, которое зависит от применяемой технологии разработки месторождений и приводит к образованию техногенных ландшафтов. Предприятия, нарушившие естественную структуру ландшафта, должны предусмотреть мероприятия по сельскохозяйственной или лесохозяйственной рекультивации. Поскольку в долине р. Колоромо отвалы вскрышных пород представлены четвертичными отложениями и по гранулометрическому составу грунты являются суглинистогравийными, наиболее целесообразным является лесохозяйственное направление рекультивации техногенных ландшасртов.

\section{Литература}

1. Золотенков Я.В. Земельные участки для проведения геологоразведочных работ перевод, изъятие, или исключение из правил? // Минеральные ресурсы России. Экономика и управление. 2014. № 6. С. 70-72.

2. Ковров А.С. Исследование видового разнообразия растительности породного отвала ликвидированной шахты «Селидовская» // Сб. науч. тр. НГА Украины. 2000. № 10.

3. Космаков В.И. Организация хозяйства в лесах, нарушенных золотодобычей. Новосибирск: Наука, 2006. 131 с.

4. Космаков В.И. Рекультивация земель, нарушенных разработками месторождений россыпного золота в Красноярском крае, как фрактор техногенного преобразования ландшафтов // Лесная таксация и лесоустройство: межвуз. сб. науч. тр. Красноярск: СибГТУ, 2005. № 1 (34). С. 175-183.

5. Пашкевич М.А. Геохимия техногенеза. СПб., 2004. 72 c.

6. Цивина И.М. Природно-техногенные комплексы и основы природообустройтва. Новочеркасск: НГМА, 2013. 79 с.

7. Экология и рекультивация техногенных ландшафтов / отв. ред. В.М. Курачев. Новосибирск: Наука, 1992. 304 с.

\section{Literatura}

1. Zolotenkov Ja.V. Zemel'nye uchastki dlja provedenija geologorazvedochnyh rabot perevod, iz\#jatie, ili iskljuchenie iz pravil? // Mineral'nye resursy Rossii. Jekonomika i upravlenie. 2014. № 6. S. 70-72.

2. Kovrov A.S. Issledovanie vidovogo raznoobrazija rastitel'nosti porodnogo otvala likvidirovannoj shahty «Selidovskaja» // Sb. nauch. tr. NGA Ukrainy. 2000. № 10.123

3. Kosmakov V.I. Organizacija hozjajstva v lesah, narushennyh zolotodobychej. Novosibirsk: Nauka, 2006. $131 \mathrm{~s}$.

4. Kosmakov V.I. Rekul'tivacija zemel', narushennyh razrabotkami mestorozhdenij rossypnogo zolota v Krasnojarskom krae, kak faktor tehnogennogo preobrazovanija landshaftov // Lesnaja taksacija i lesoustrojstvo: mezhvuz. sb. nauch. tr. Krasnojarsk: SibGTU, 2005. № 1 (34). S. 175183.

5. Pashkevich M.A. Geohimija tehnogeneza. SPb., 2004. $72 \mathrm{~s}$.

6. Civina I.M. Prirodno-tehnogennye kompleksy i osnovy prirodoobustrojtva. Novocherkassk: NGMA, 2013. $79 \mathrm{~s}$.

7. Jekologija i rekul'tivacija tehnogennyh landshaftov / otv. red. V.M. Kurachev. Novosibirsk: Nauka, 1992. $304 \mathrm{~s}$. 